\title{
Liability of a Technical Supervisor of Construction: Analysis of Lithuanian Case Law
}

\author{
Sigitas Mitkus \\ Department of Law, Vilnius Gediminas Technical University, Vilnius, Lithuania \\ E-mail: sigitas.mitkus@vgtu.lt
}

Received 22 February 2017; accepted 11 April 2017

\begin{abstract}
The article deals with the liability issues of a technical supervisor of construction in Lithuania. It is established in statutory law that a technical supervisor of construction is liable against an owner jointly with other parties involved in the construction (contractor, designer); however, it provides no explanation as to how this liability is distributed between the parties. Analysis of case law of the Supreme Court of Lithuania is used as a basis for crystallizing the rules applied by the courts in defining liability of a technical supervisor of construction and distributing it between other construction players. It has been found out that the liability attributed in case law to the technical supervisor of construction found guilty for defective construction works usually varies from $15 \%$ to $20 \%$. The findings of this research may be used in systems for predicting court judgements and decision support systems for judicial disputes.
\end{abstract}

Keywords: case law, supervising of construction, construction management, civil liability, quality of construction works, contractor.

JEL Classification: L74, K22, M11.

Conference topic: Modern Business Management Problems and Perspectives.

\section{Introduction}

The Law on Construction, which is the primary legal source regulating public construction, defines a technical supervision of the construction of a construction works as one of the main areas of technical construction activities. Supervision of the construction of a construction works is the activity organised by the owner, the purpose of which is to control if the construction is carried out in compliance with:

- the design documentation of a construction works;

- the requirements of the contract;

- the requirements of laws and regulations.

The status of a technical supervisor of the construction is also defined by the Law on Construction. The main characteristics of the technical supervisor are as follow:

- a natural person: an architect or a civil engineer;

- holder of a relevant qualification certificate;

- represents the owner;

- heads engineering supervision of the construction of a construction works;

- performs functions assigned to the head of general technical supervision of the construction of a construction works;

- co-ordinates special supervision of the construction of a construction works and activities of the heads thereof;

- within the sphere of his competence, is responsible for the quality of the construction works.

The rights and duties of a technical supervisor of the construction are laid down in detail in the Law on Construction and Technical Construction Regulation STR 1.06.01:2016 "Construction works. Supervision of construction works". An owner may delegate the organisation of the technical supervision of the construction of a construction works to a manager of the construction of a construction works or to a contractor of the supervision of a construction works who may be a legal person. In the latter case, legal entities act on the contract of agency and are liable against the owner for the selection of the appropriate technical supervisor of the construction and other contractual obligations.

(C) 2017 S. Mitkus. Published by VGTU Press. This is an open-access article distributed under the terms of the Creative Commons Attribution (CC BY 4.0) License, which permits unrestricted use, distribution, and reproduction in any medium, provided the original author and source are credited. 
In any case, the status of the technical supervisor of the construction of a construction works is applicable only to a person designated and appointed to act as such.

Liability of the technical supervisor of the construction is regulated by the Law on Construction and by a higher legally binding document, i.e. the Civil Code. The Civil Code makes a distinction between four entities: contractor, designer, technical supervisor of the construction and contractor of expertise of design who are liable for:

- the collapse of a structure and the resultant damage (Article 6.696(1) (Lietuvos Respublikos Seimas (LRS) 2000));

- the defects discovered within the warranty period (Article 6.697(3) (Lietuvos Respublikos Seimas (LRS) 2000)).

Particularities of the liability of participants of construction projects are studied in deep by scholars (Zaneldin 2006; Choi et al. 2015; Shih-hung 2013; Huang, Hinze 2006; Huang, Chang 2009; Gambatese et al. 2005; Chang 2013; Jamshidi, Hatefi 2016; Bakhary et al. 2015; Tan, Anumba 2010; Charoenngam, Yeh 1999; Mitkus 2005; Elovitz 2001; Klimas 2011; Arditi, Pulket 2005; Chaphalkar et al. 2015; Saukalienè 2010). The liability of technical supervisor of construction is not in deep analyzed, however.

Most of conflicts in construction are related to quality of construction works (Mitkus, S., Mitkus, T. 2014a, 2014b; Mitkus 2016; Mahamid 2016; Yildizel et al. 2016; Cibulskienė, Mitkus 2016). The responsibilities of a technical supervisor of construction are mainly related to supervising of quality of construction works. Therefore, research of the liability issues of a technical supervisor of construction could significantly impact to practical juridical relations between participants of construction projects.

A supervisor of construction can not be liable for defects or other damages alone. He always is sharing the liability with the contractor, designer or owner. The way, how the liability should be shared is not specified by statutory law. The aim of the article is to find out what rules of sharing liability is stated in Lithuanian case law. The main method applied for the research is a comparative research of the case law of the Supreme Court of Lithuania.

\section{The First Stage of Establishing Liability of a Technical Supervisor in Case-Law}

The beginning of the modern civil law of Lithuanian Republic should be seen year 2001, when current Civil Code came into force (before was valid Soviet Civil Code). It was therefore examined Lithuanian case law which arose from legal construction relationships arising after this date. All rulings of the Supreme Court of Lithuanian concerning liability of a technical supervisor of construction are examined in the paper.

The issue concerning liability of a technical supervisor of the construction was first examined in the case law of the Supreme Court of Lithuania in the ruling of 22 June 2006 (Supreme Court of Lithuania 2006). TÜB Vikensta applied to the court claiming to order the defendant UAB Skala to pay LTL 112594 of completed construction costs to eliminate the defects discovered within the warranty period. The following facts were found out by the courts:

- the warranty period set by the parties to the contract was 5 year and the following defects of the building were discovered during the warranty period: cavities in external and internal walls, base slabs, floors of the first floor, leaking roof, insufficient horizontal and vertical waterproofing;

- the cause of the defects was deviations from the design documentation in the process of construction;

- the design documentation was altered arbitrary, without permission of the project designer and without conducting expert examination of the altered design documentation;

- the construction of the construction works was not supervised by the technical supervisor of the construction. The defendant did not contest the fact of defects.

Both a district court and a county court decided that contractor is completely liable against owner on the ground of Article 6.659 of the Civil Code (Lietuvos Respublikos Seimas (LRS) 2000), because the contractor did not warn owner about possible subsequences of the changes of the design documentation. The Supreme Court of Lithuania changed the decisions.

The Supreme Court of Lithuania noted that if defects of a construction works are found, it is important, in the context of liability of the contractor, designer or technical supervisor, to identify the cause(s) of the defects in each particular case and to link the cause(s) to omissions or improper performance by persons liable for the defects. Deviations from the design documentation, which were the causes underlying the defects, were made on owner's request. However, the court ruled that the consequences of such requests was the liability of the contractor because he was required to warn the customer about the circumstances; failing this, the contractor is kept liable for the defects (Article 6.659(1)(2) of the Civil Code (Lietuvos Respublikos Seimas (LRS) 2000)). The Court further established that the liability of the contractor should be reduced on the following grounds:

1. wrong instructions to the contractor were given by the owner;

2. the owner, at the same time being the technical supervisor of the construction, failed to conduct technical supervision of the construction (in accordance with legal acts valid at the moment of construction contracting, the owner, as a legal entity, was allowed to act in parallel as the technical supervisor of the construction). 
The Supreme Court of Lithuania ruled that the liability of the contractor should be reduced by $40 \%$ due to the mentioned circumstances. The Court did not specify the proportion of reduced parts of the liability falling on each reason. However, taking into account a $25 \%$ reduction of liability in analogue situations when technical supervision was not obligatory (see civil case No 3K-3-396 below), it can be concluded that the Court reduced the liability as follows:

1. by $25 \%$ n on the ground of wrong instruction given to the contractor by the builder (customer);

2. by $15 \%$ due to owner's failure to conduct technical supervision.

In civil case No 3K-3-396/2008 (Supreme Court of Lithuania 2008b), plaintiff $A$. G. applied to the court to order payment of debt and default interest in the amount of LTL 6000 from defendant $A$. S. The court found out that the plaintiff was obliged to repair the roof in the defendant's building by fixing likely leaking spots with separate patches in accordance with the contract of 29 October 2004. The plaintiff performed the works agreed in the contract. Having examined the evidence in the case, the courts established that the roofing repair works under the contract between the parties were performed without any material defects. Therefore, the plaintiff was entitled to claim payment for the works from the defendant.

It was established in this case that although the works performed by the Plaintiff were in compliance with the contractual requirements and conditions, and the court of appeals recognised the duty of the defendant to pay the plaintiff for the works on a well-founded basis, these works virtually failed to produce the result expected by the defendant upon signing the contract, i.e. overall roof leakage was not eliminated. The plaintiff, who was construction professional and acted on his own risk, performed roof patching works in specific areas of the roof in accordance with defendant's instructions. The plaintiff was (or should have been) aware that the fulfilment of the defendant's instructions may have negative consequences on the fitness of the works but he failed to warn the defendant to his effect.

The Supreme Court of Lithuania upheld the judgement of the district court of Vilnius city whereby the plaintiff was adjudged LTL 3000. Considering that the value of the contract was LTL 12000, it can be concluded that the court reduced the price for work by $25 \%$ due to the improper instructions of the customer.

In civil case No 3-K-3-585/2008 (Supreme Court of Lithuania 2008c), there was a dispute between the parties regarding defendant's duty to pay the remaining part of the price for the works performed under the contract of independent works (LTL 113 300) and the plaintiff's duty to compensate the defendant for the costs of elimination of defects in the construction works discovered within the guarantee period (LTL 170 818).

The Regional Court of Panevėžys satisfied the Plaintiff's claim and defendant's counterclaim in part, by awarding LTL 32762 from the Plaintiff in favour of the defendant in compensation for the costs of elimination of defects in the construction works discovered within the warranty period. The engineering examination found that the plaintiff deviated from the design documentation in performance of construction works, but some of the deviations from the design documentation were made on request or in agreement with the owner. The court ruled that the plaintiff was liable against the defendant for the defects in accordance with the construction contract and under the law. A greater portion of liability for the consequences of owner's requests identified in this case fell onto the plaintiff whose duty was to warn the defendant; failing this, the plaintiff was kept liable for the defects of works. The court further ruled that there were grounds to reduce the contractor's (plaintiff's) liability (Articles 6.259(1), 6.689 (2) and (4), 6.697(3) of the Civil Code (Lietuvos Respublikos Seimas (LRS) 2000)), because the right to control and supervise construction works was the duty of the defendant (Article 6.689(1) of the Civil Code (Lietuvos Respublikos Seimas (LRS) 2000)) and the works were controlled by the technical supervisor of construction appointed by the defendant. The plaintiff deviated from the general requirements of statutory regulations, failed to warn the defendant about likely negative consequences and fulfilled the defendant's requests, whereas the latter initiated and influenced the deviations from the design documentation; technical supervision and control of construction was carried out by defendant's agent. Accordingly, both the defendant and the plaintiff were liable for the consequences. As the plaintiff did not agree to eliminate the discovered defects by the time limit provided by the defendant, the latter had the right, at his choice, to require reduction of the price established for work and compensation of his expenses for elimination of the defects (paragraphs 2 and 3 of Article 6.665(1) of the Civil Code (Lietuvos Respublikos Seimas (LRS) 2000)). The court established that the cost of elimination of the discovered defects was LTL 210 102, but the expenses for elimination of the defects awarded to the Respondent from the Plaintiff should be reduced by $40 \%$.

The Supreme Court of Lithuania upheld in essence the judgement of the regional court. The Supreme Court of Lithuania pointed out that, in accordance with the judgements rendered in the case, on the basis of the findings of the expert examination and facts of the case, it was established in the case at issue that the main cause of the defects was deviation from the project documentation due to the contractor's and owner's fault on request of the customer. The courts established that the contractor deviated from the design documentation, failed to adhere to the requirements of statutory regulations, failed to warn the customer about likely negative consequences and continued to fulfil the owner's requests, whereas the latter initiated and influenced the deviations from the design documentation; technical supervision and control of construction was carried out by owner's agent. Basing on the arguments above, the court concluded that both the defendant and the plaintiff were liable for the construction defects (Article 6.248(4) of the Civil Code (Lietuvos Respublikos Seimas (LRS) 2000)). The law stipulates that the contractor is obliged to immediately warn the customer and until receiving instructions from him to suspend the work in the event of discovering 
possible consequences threatening the fitness or stability of the work due to the compliance with the instructions of the customer concerning the methods of the fulfilment of work; failing to warn the customer about such circumstances, the contractor forfeits his right to refer to the aforementioned circumstances and is liable for the defects of the thing (Article 6.659(1), (2) of the Civil Code (Lietuvos Respublikos Seimas (LRS) 2000)). The Supreme Court of Lithuania ruled out that the courts of lower instances had justly distributed the liability between the contractor and the respondent.

In this case, the courts fully observed case law developed in civil case No 3K-3-135/2006. Therefore, it can be concluded that the courts reduced the liability of the contractor for improper technical supervision of construction by $15 \%$.

Some deviation from consistently developed case law was observed in civil case No 3K-3-343/2009 (Supreme Court of Lithuania 2009). In this case, there was a dispute between the sub-subcontractor and subcontractor. The defendant (subsubcontractor) undertook to perform fountain installation works in accordance with the construction contract. The quality of the works was substandard and the defendant failed to eliminate the defects. The plaintiff (subcontractor) terminated the contract and applied to court for adjudging damages.

In this case, the cause of defects was poor building materials supplied by the plaintiff. The courts found out that the defendant was able to identify the poor quality of the building materials both visually and on the basis of conformity documents that must have been claimed from the plaintiff. Such actions were qualified as giving defective instruction and fulfilment thereof. Following the above-mentioned case-law, liability should have been distributed between the parties and the liability for the non-execution of technical supervision should have been defined. However, in this case, the courts ruled that the sub-subcontractor should bear total liability which was not reduced on the ground that the defective instructions to use building materials of substandard quality were given by the subcontractor (professional construction contractor).

In the case above, the courts did not judge on the liability for poor technical supervision; in accordance with the Law on Construction, the technical supervisor of the construction is obliged to prevent the use of substandard building materials in construction. Such a decision of the courts in this regard could be explained by the fact that technical supervision must have been organised by the owner, not the subcontractor, moreover that the parties did not bring the issue of the liability of the technical supervisor of construction. Therefore, it can be concluded that there was no deviation from case-law with regard to the liability of technical supervisors.

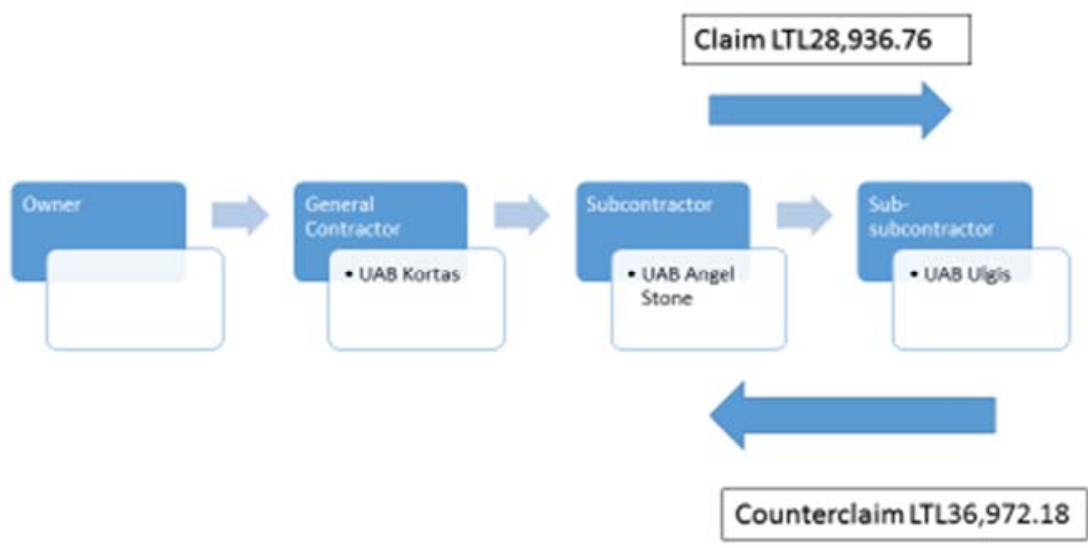

Fig. 1. Scheme of contractual relationship and judicial dispute in civil case No 3K-3-343/2009 (Source: developed by author)

It was further established in case law that technical supervisors are not always liable for defective works of contractors. In civil case No 3K-3-575/2008 (Supreme Court of Lithuania 2008a), the courts found out that the plaintiff performed installation of concrete floors in the building, but the plaintiff did not sign the statement of acceptance of works and filed a claim regarding the quality of works. Although the construction contract provided for the plaintiff's duty to perform technical supervision, the courts failed to establish that plaintiff's acts could have any influence on the quality of construction works.

Summarized results showing liability shares for defective constructions works, when technical supervisors of the construction works are involved is shown in Figure 2. 


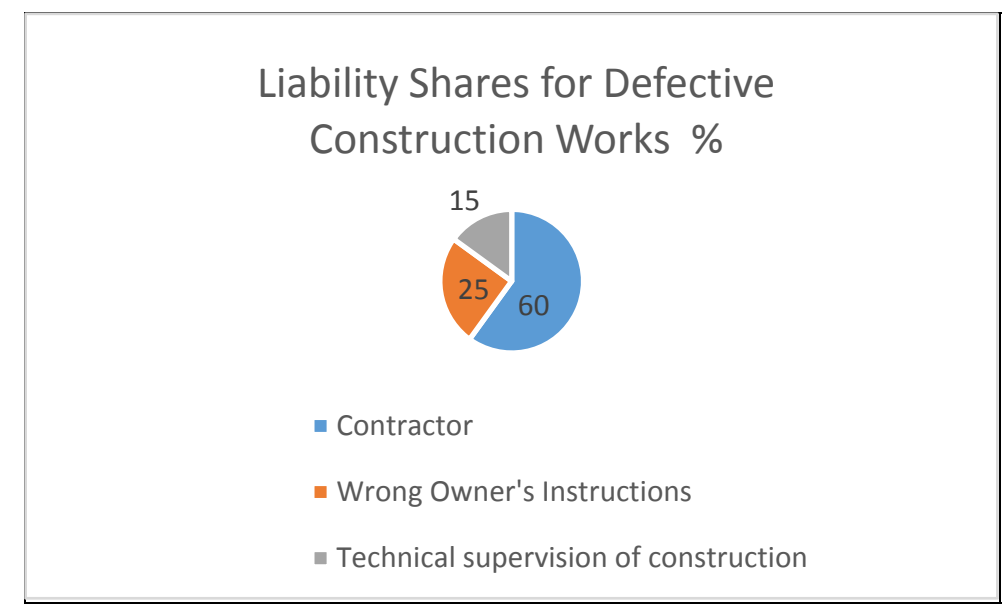

Fig. 2. Liability shares for the defective construction works according Lithuanian case law (Source: developed by author)

\section{The Second Stage of Establishing Liability of a Technical Supervisor in Case-Law}

Within a period from 2009 to 2013, there were no proceedings heard by Supreme Court of Lithuania in relation to the legal liability of technical supervisors of construction. However, there were proceedings of this type in 2014 showing some variations in the case law.

Contractor UAB Klaipedos hidrotechnika applied to the court to adjudge payment of debt in the amount of LTL 1299606 from owner State Enterprise Klaipeda State Seaport Authority (Supreme Court of Lithuania 2014a) for elimination of defects. It was established in this case that in 2004 the plaintiff and the defendant entered into contract of independent construction works No 34-2004-566 for reconstruction of quay No 142. The plaintiff undertook to perform the works of construction of the quay and bank revetment at the Malku Bay. After the works, there appeared gaps in the connecting wall of the quay. The Plaintiff eliminated defects at its own expense and claimed compensation from the owner, stating that the defects appeared due to the owner's fault.

In this case, the contractor did not assume liability for the defects and supported its position on the following grounds:

- the cause of the defects was defective instructions of the customer: the method of performing the works in the technical design documentation submitted by the customer was defective (bulkheads and sheet piling), but fulfilment of owner's instructions is obligatory for the contractor;

- the customer was at the same time the technical supervisor and, as such, must bear the liability for deviations from the design documentation;

- the owner was aware of the deviations and this according to the plaintiff is equal to the owner's instruction which is obligatory for the contractor.

The Supreme Courte of Lithuania paid attention that the owner was not the technical supervisor. In compliance with the Law on Construction, the customer organises technical supervision by appointing or hiring a technical supervisor of construction. The Law on Construction further stipulates that the technical supervisor must be a natural person. Therefore, the customer and the technical supervisor are two different participants in the process of construction and cannot be identified with. Where technical supervision is carried out by the owner's employee appointed to act as the technical supervisor and such employee fails in performance of his duties, the owner's liability may arise not from the violation of his duties as that of the party to the contract of independent construction works, but as that of the entity hiring the employee (technical supervisor in the case at issue).

This was the beginning of developing new case law (before that, courts would held that the customer is liable for improper performance or non-performance of technical supervision).

The analogue position was held by The Supreme Court of Lithuania in a ruling adopted two day later in civil case No 3-K-3-20/2014 (Supreme Court of Lithuania 2014b). In the given case, the user of the building, DNSB Taurakalnio namai, filed a claim for damages against contractor $U A B$ Santechnikos verslas. The court found out that, in accordance with the contract of independent construction works between the plaintiff and the contractor, UAB Sklypo servisas performed installation and assembling of the domestic water supply system and wastewater, rainwater and condensate piping in a multi-apartment building. During the warranty period, the plaintiff discovered that the wastewater disposal pipe is leaking in the car parking area.

In order to shirk liability, the defendant claimed that a part of the liability for defects should fall onto the owner who performed technical supervision. However, The Supreme Court of Lithuania reiterated the arguments laid down in civil case No 3K-3-20/2014 and noted that the owner and the technical supervisor are two difference participants in the construction process and the customer cannot assume liability for the acts of another participant of the construction project. 
The Supreme Court of Lithuania further held that the courts of lower instances should have satisfied the defendant's request to engage the persons who performed the technical supervision as third persons in the case. However, The Supreme Court of Lithuania also established that this cannot serve as a basis for overruling. If the defendant thinks that the technical supervisor of the construction is also liable for the defects, the defendant has the right to claim damages caused by the wrongful acts of the technical supervisor of the construction.

The latter ruling could have significant practical applications. There were a number of legal cases related to quality (defects), when the liability of technical supervisor was not raised (for example Supreme Court of Lithuania $2005,2007,2010,2011)$. Therefore the contractor who has been unsuccessful in the case due to defects can claim the technical supervisor of construction to compensate a part of the lost sum, if the contractor considers that the technical supervisor of the construction is also guilty for the defects.

In civil case No 3K-3-389-969/2015 (Supreme Court of Lithuania 2015), the courts slightly deviated from their stance with regards to a portion of liability falling onto the technical supervisor of construction. Owner II Seno dvaro sodyba filed a claim against contractor Rustonas, requesting, inter alia, elimination of construction defects. The contractor was obliged to build a café motel in accordance with the construction contract. Forensic engineering examination found that heat insulation of flooring, ceiling and roofing structures was of substandard quality; the contractor use insulation wool of inappropriate quality; layers were not overlapping; steam insulation on the roof was absent; the roof was cold and a cold bridge occurred in the kitchen zone which damaged the finishing of the plasterboards and caused gaps in the wall junctions. As the owner failed to hire technical supervisor, the courts reduced the contractor's liability by $10 \%$. This amount slightly differed from $15 \%$ previously developed in case law.

The portion of liability falling onto the technical supervisor was also ruled in civil case No 3K-3-389-915/2016 (Supreme Court of Lithuania 2016). In this case, the Supreme Court of Lithuania judged on the customer's liability for non-organising technical supervision of construction.

Plaintiff $L . K$. applied to the court to order defendant $L . \check{S}$. to pay EUR 32759.73 for damages. The defendant requested the court to order the plaintiff to pay a debt in the amount of EUR 16 962.47. The plaintiff stated that she and the defendant agreed that the latter would build a log house (wooden balks and roof structures) on the plaintiff's plot of land with defendant's own materials, means and resources for EUR 14 481, interior finishing and equipment excluded. Interior finishing of the dwelling house started in 2008 after the defendant accomplished the construction of the house. The interior finishing works were carried out by other contractors. The construction of the dwelling house was completely finished at the end of 2010.

The District Court of Panevėžys City satisfied the claim in part by ordering the defendant to pay the plaintiff EUR 5495.97 for damages. It was established in the court that the forensic engineering examination of 10 April 2013 found out as follows: (1) construction of the bottom logs on the foundation was not compliant with the standard requirements; the defect occurred due to designer's acts resulting from bad design solution (designed dimensions of the foundation were lager than the dimensions of the first floor); (2) the walls of the house were poorly bonded with each other; the defect occurred due to the acts (omissions) of the contractor and supervisor of the construction works; (3) wall verticality did not meet the standard requirements; the cause of the defect (poor wall bonding) had to be discovered by the technical supervisor of the construction works; (4) cracks in logs and beams were not compliant with the standard requirements; the defect occurred due to contractor's fault, but the non-compliance of some of the cracks with the standard requirements could have been detected by the technical supervisor of the construction during a visual inspection; (5) cavities between logs were not compliant with the standard requirements; the defect occurred due to contractor's fault, but the non-compliance of some of the cavities with the standard requirements could have also been detected by the technical supervisor of the construction works during a visual inspection; (6) wall evenness was not compliant with the standard requirements; the defect occurred due to contractor's fault, inadequate preparation and/or laying of beams.

Having analysed the conclusive findings of the expert examinations, the court established that the material defects of the construction works resulted from the acts (omissions) of the contractor, designer and technical supervisor, as well as due to plaintiff's acts (omissions), because the latter had a duty to organise and conduct technical supervision of the construction of the construction works (Article 12(1)(5) of the Law on Construction (Lietuvos Respublikos Seimas (LRS) 1996)). The plaintiff failed to perform this duty, was negligent, failed to act with sufficient diligence and thereby assumed the risk of occurrence of construction defects.

The court pointed out that the defendant failed to deny the presumption of defendant's fault with regard to the defects in the construction of the house; the Respondent's fault accounted for $50 \%$ due to the established wrongful acts of other parties (designer, technical supervisor and plaintiff). Therefore, the defendant was ordered to pay the defendant 1/2 part of the costs found by the court necessary for the elimination of the defects, i.e. EUR 5 495.97.

The Regional Court of Panevėžys upheld the judgement of the District Court of Panevėžys City in the part regarding the distribution of liability. However, the Supreme Court of Lithuania quashed the above-mentioned judgements and changed the distribution of liability. Instead of $50 \%$ of liability on the part of the Respondent, the Supreme Court of Lithuania ruled that the contractor's liability for the defects was $85 \%$ and the owner's liability was $15 \%$. The court did not explain the reason for deviating from the case law developed in civil case No 3K-3-389-969/2015 (liability was reduced by $10 \%$ ), but by this decision the court came back to previous case law rules (see Fig. 2). 


\section{Conclusions}

Lithuanian case law developed with regard to the liability of technical supervisors of construction can be divided into two phases: (1) 2006-2009 and (2) from 2014.

The courts make a distinction between two types of liability arising in relation to technical supervision of construction:

- failure to organise technical supervision of the construction by the owner whose duty is to organise it;

- technical supervision is organised by the owner, but it is defectively performed by the technical supervisor of the construction.

In any of the above cases, in order to establish liability to the owner or technical supervisor, it is necessary to find a causal link between the not performed or improperly performed technical supervision of construction and the damage (defects) caused.

The owner may be held liable for the non-performance of technical supervision of the construction only if he was obliged to organise the technical supervision of the construction and failed to do so. The owner is considered to have failed to organise the technical supervision of the construction even in such cases when he enters into a formal agreement with the technical supervisor of construction but fails to organise the technical supervision in fact.

The courts do not held customer liable for the improper performance of technical supervision of construction, if the owner appoints the technical supervisor of the construction in a due manner. Owner's liability for the improper performance of technical supervision of construction does not arise even in the case of hiring the technical supervisor of the construction under a contract of employment, i.e. the technical supervisor is the owner's employee. In the latter case, only an independent participant of construction (technical supervisor of construction) may be held liable.

The portion of liability for the non-performance or improper performance of technical supervision varies from 10 to15 percent in the case law. Clear criteria for establishing the portion of liability for technical supervision of the construction have not been identified. The results of the research could be used for a prediction of outcomes of construction dispute claims (Chaphalkar et al. 2015; Mahfouz et al. 2016) or for decision support systems for dispute resolution (Carneiro et al. 2013; Keršulienè et al. 2010)

\section{References}

Arditi, D.; Pulket, T. 2005. Predicting the outcome of construction litigation using boosted decision trees, Journal of Computing in Civil Engineering 19(4): 387-393. https://doi.org/10.1061/(ASCE)0887-3801(2005)19:4(387)

Bakhary, N. A.; Adnan, H.; Ibrahim, A. 2015. A study of construction claim management problems in Malaysia, Procedia Economics and Finance 23: 63-70. https://doi.org/10.1016/S2212-5671(15)00327-5

Carneiro, D.; Novais, P.; Andrade, F.; Zeleznikow, J.; Neves, J. 2013. Using Case-Based Reasoning and Principled Negotiation to provide decision support for dispute resolution, Knowledge and Information Systems 36(3): 789-826. https://doi.org/10.1007/s10115-012-0563-0

Chang, S. H. 2013. Evaluating essential liabilities on design professionals under earthquake's impact: Taiwan experience, Engineering, Construction and Architectural Management 20(2): 181-194. https://doi.org/10.1108/09699981311303035

Chaphalkar, N. B.; Iyer, K. C.; Patil, S. K. 2015. Prediction of outcome of construction dispute claims using multilayer perceptron neural network model, International Journal of Project Management 33(8): 1827-1835. https://doi.org/10.1016/j.ijproman.2015.09.002

Charoenngam, C.; Yeh, C. Y. 1999. Contractual risk and liability sharing in hydropower construction, International Journal of Project Management 17(1): 29-37. https://doi.org/10.1016/S0263-7863(97)00064-1

Choi, K.; Lee, H. W.; Bae, J.; Bilbo, D. 2015. Time-cost performance effect of change orders from accelerated contract provisions, Journal of Construction Engineering and Management 142(3): 04015085. https://doi.org/10.1061/(ASCE)CO.19437862.0001071

Cibulskienè, R; Mitkus, S. 2016. The concept of builder and its liability for the quality of the construction works in Lithuanian construction law, in The $9^{\text {th }}$ International Scientific Conference "Business and Management 2016", 12-13 May 2016, Vilnius, Lithuania, 1-9.

Elovitz, K. M. 2001. Legal liabilities of engineers, building officials: your professional choices and the legal risks that result, Heating/piping/air conditioning engineering 73(5): 33-42.

Gambatese, J. A.; Behm, M.; Hinze, J. W. 2005. Liability of designing for construction worker safety, Journal of construction engineering and management 131(9): 1029-1036. https://doi.org/10.1061/(ASCE)0733-9364(2005)131:9(1029)

Huang, Y. L.; Chang, S. H. 2009. Design professionals' legal risks increased under nature's attack: Chichi Earthquake experience, International Journal of Project Management 27(6): 544-551. https://doi.org/10.1016/j.ijproman.2008.10.008

Huang, X.; Hinze, J. 2006. Owner's role in construction safety, Journal of Construction Engineering and Management 132(2): 164 173. https://doi.org/10.1061/(ASCE)0733-9364(2006)132:2(164)

Yildizel, S. A.; Dogan, E.; Kaplan, G.; Ergut, A. 2016. Major constructional dispute causes in Turkey, Archives of Civil Engineering 62(4): 193-204. https://doi.org/10.1515/ace-2015-0116

Jamshidi, S. F.; Hatefi, S. M. 2016. Identification of reasons for claims of contractors in DBB contracts and evaluation by multicriteria decision-making models (ALH), Iran University of Science \& Technology 6(4): 557-566. 
Keršulienė, V.; Zavadskas, E. K; Turskis, Z. 2010. Selection of rational dispute resolution method by applying new step $\square$ wise weight assessment ratio analysis (SWARA), Journal of Business Economics and Management 11(2): 243-258. https://doi.org/10.3846/jbem.2010.12

Klimas, E. 2011. A general duty to co-operate in construction contracts? An international review, International Journal of Law in the Built Environment 3(1): 83-96. https://doi.org/10.1108/17561451111122624

Lietuvos Respublikos Seimas (LRS). 1996. Law on Construction, Valstybès žinios 32(788).

Lietuvos Respublikos Seimas (LRS). 2000. Civil Code of the Republic of Lithuania, Valstybès žinios 74(2262).

Mahamid, I. 2016. Micro and macro level of dispute causes in residential building projects: studies of Saudi Arabia, Journal of King Saud University-Engineering Sciences 28(1): 12-20. https://doi.org/10.1016/j.jksues.2014.03.002

Mahfouz, T.; Davlyatov, S; Kandil, A. 2016. Analysis of differing site condition (DSC) litigation reasoning through statistical modeling, International Journal of Construction Education and Research 12(4): 285-302. https://doi.org/10.1080/15578771.2016.1172140

Minister of Environment of Lithuanian Republic. 2016. Technical regulation of construction STR 1.06.01:2016 "Construction works. Supervising of construction”. Register of juridical acts, 2016-12-05, 2016 (28228).

Mitkus, S. 2005. Graphical risk and liability allocation models in construction contracts, Foundations of Civil and Environmental Engineering 6: 129-144.

Mitkus, S.; Mitkus, T. 2014a. Application of constructs in commercial dispute resolution, in The $8^{\text {th }}$ International Scientific Conference "Business and Management 2014", 15-16 May 2014, Vilnius, Lithuania, 109-117.

Mitkus, S.; Mitkus, T. 2014b. Causes of conflicts in a construction industry: a communicational approach, Procedia-Social and Behavioral Sciences 110: 777-786. https://doi.org/10.1016/j.sbspro.2013.12.922

Mitkus, T. 2016. Identifying causes of disputes in creative industries: Lithuanian architecture segment case study, in The $9^{\text {th }}$ International Scientific Conference "Business and Management 2016”, 12-13 May 2016, Vilnius, Lithuania, 1-8.

Saukalienè, K. 2010. Construction defects and problems of owner liability, Socialiniu mokslu studijos (2): 243-257.

Shih-hung, C. 2013. Evaluating essential liabilities on design professionals under earthquake's impact, Engineering, Construction and Architectural Management 20(2): 181-202. https://doi.org/10.1108/09699981311303035

Supreme Court of Lithuania, 2005. A.S. individuali ịmone v. UAB “Abuva”. Case No. 3K-3-538/2005.

Supreme Court of Lithuania. 2006. TÜB Vikensta v. UAB Skala. Case No. 3K-3-135/2006.

Supreme Court of Lithuania. 2007. UAB "Damava" v. R.E.C., Case No. 3K-3-66/2007

Supreme Court of Lithuania. 2008a. UAB Valviktè v. UAB UAB Laugina. Case No. 3K-3-575/2008.

Supreme Court of Lithuania. 2008b. A.G. v. A. S. Case No. 3K-3-396/2008.

Supreme Court of Lithuania. 2008c. UAB Agaras v. UAB Laugina. Case No. 3K-3-585/2008.

Supreme Court of Lithuania. 2009. UAB Angel Stone v. UAB Ulgis. Case No. 3K-3-343/2009.

Supreme Court of Lithuania. 2010. UAB “Jaukurai" v. BUAB "Forsitia”. Case No. 3K-3-469/2010.

Supreme Court of Lithuania. 2011. UAB "Vaivorykšte” v. UAB “AR10”. Case No. 3K-3-115/2011.

Supreme Court of Lithuania. 2014a. UAB Klaipedos hidrotechnika v. State Enterprise Klaipeda State Seaport Authority. Case No. 3K-3-492/2014.

Supreme Court of Lithuania. 2014b. BNSB Taurakalnio namai v. UAB Santechnikos verslas. Case No. 3K-3-20/2014.

Supreme Court of Lithuania. 2015. UAB Seno dvaro sodyba v. UAB Rustonas. Case No. 3K-3-389-969/2015.

Supreme Court of Lithuania. 2016. L.K. v. L.S̆. Case No. 3K-3-389-915/2016.

Tan, H. C.; Anumba, C. J. 2010. Web-based construction claims management system: a conceptual framework, in Proceedings of the $8^{\text {th }}$ International Conference on Construction and Real Estate Management (ICCREM 2010): 1-3.

Zaneldin, E. K. 2006. Construction claims in United Arab Emirates: types, causes, and frequency, International Journal of Project Management 24(5): 453-459. https://doi.org/10.1016/j.ijproman.2006.02.006 